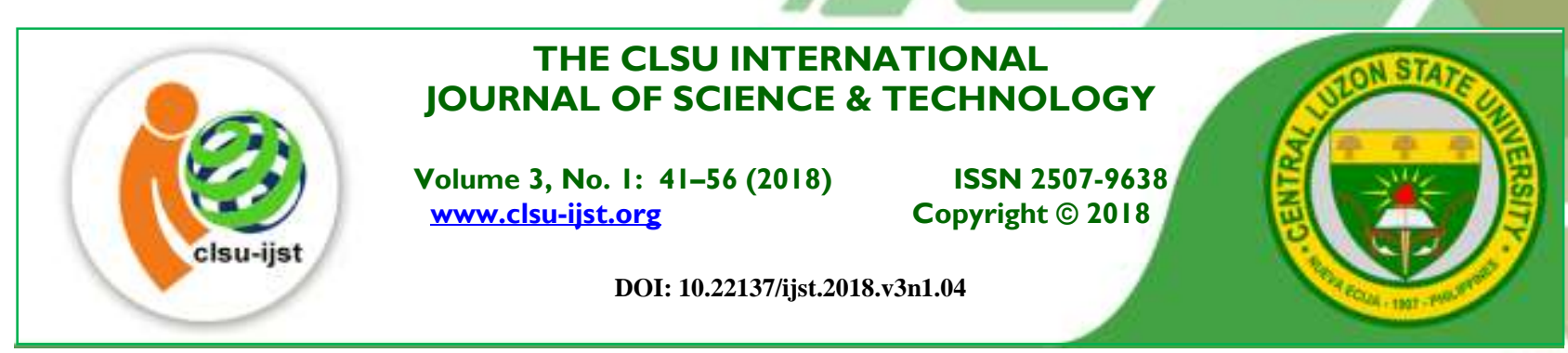

\title{
The Entrepreneurial and B2B Linkage Management of Traditional Dairy Communities in Central Luzon, Philippines
}

\author{
Matilde Melicent Santos-Recto
}

Central Luzon State University, Science City of Munoz, Nueva Ecija, Philippines

Email for correspondence: voudaque@yahoo.com.ph

\begin{abstract}
The research expounded the profiles of two sectoral players, the supply-side players who are the carabao milk producers and the demand-side players who are the milk processors; characterized the business process relational practices of the two sectors; determined the best entrepreneurial and management activities and setbacks of the strategic partnership relations; and finally presented a relational and linkage model to synergize and reconfigure the B2B connections of the Carabao Milk to Pastillas Chain Model. Findings showed that there was only a barely conspicuous link between the two sectors to be able to determine a verifiable carabao milk and pastillas chain. The link was perceptible only in a few fields of B2B BPM practices. To form a strong link between the two sectors, the coordinated Single Step Demand-Driven Carabao Milk-Pastillas Chain Model was proposed to ally the two sectors through the Five-Fields Synergy System Model of Linkage Management which was placed in-between the sectors on the assumption that the carabao milk market acts on a demand-driven supply chain principle. Taken in its generic form, the model can be applied to other base commodities of any two or more agri-food sectors as long as there is a coordinating body that will serve as the core.
\end{abstract}

Key Words: business to business (B2B), business process management (BPM), demand-driven supply chain, enterprise development, strategic management.

\section{INTRODUCTION}

The existing challenges faced by development practitioners and training and extension institutes rest on the upgrading of human capital and the promotion of equitable and sustainable development practices with the poor segment of the society at the grassroots level (MacDonald, 1999; NEDA-WB, 2007). This is provided by a comprehensive approach that integrates the various components of government-controlled community-based efforts (Wall, 2000). Community processes, which include empowerment, social networks, and social integration, have significant effects on the ability of the communities to adopt and implement community development strategies (NEDA-WB, 2003). From out of the Philippine Carabao Center's Genetic Improvement Program (PCC-GIP), a carabao-based platform of community development has been adopted to form a community base of 
farmers engaged in carabao milk production. The Carabao-Based Enterprise Development (CBED) program is one of the major programs of the Philippine Carabao Center (PCC) based on the PCC-GIP that provides for the creation of carabao-based livelihood opportunities for smallhold farmers in traditional communities. This facilitates farmers to organize themselves into cooperatives and endows them with technical and social preparations so that they can engage in carabao dairy production.

The Province of Nueva Ecija, Philippines was initiated as the National Impact Zone (NIZ), serving as the working model of community development that is based on the genetically improved carabao. As a community model of development, it initiates cooperativism as a countryside development scheme for the smallhold farmers and the Comprehensive Agrarian Reform Program (CARP) beneficiaries. Through the establishment of dairy cooperatives, farmers can gain access to resources, participate in decision-making, and develop their potentials for business and viable enterprises.

\section{OBJECTIVES OF THE STUDY}

The core of the study is founded on the primary inquiry: How did government-induced innovations develop the traditional community-based carabao dairy industry from the supply side to the demand side of the carabao milk chain?

To find answers to the aforesaid queries, this study aimed to resolve the following objectives:

1. Determine the traditional business to business (B2B) characteristics describing the transactional and relational linkages of the supply and demand sectors in the carabao dairy industry

2. Describe the dynamics of interaction between the supply and demand entities of the carabao milk and pastillas chain

3. Find out the significance of the institutional factors in the forging of nexus among the sectoral players of the traditional community-based dairy industry

4. Configure the carabao milk chain, approximate particular predictors of sustainability, and identify areas of potential replication

5. Recommend policy proposals to fill in the knowledge gaps and address problems besetting the government-sponsored innovation

\section{CONCEPTUAL FRAMEWORK}

The dynamism of government-induced innovations on the native carabao for the development of the traditional community-based dairy carabao industry in terms entrepreneurial endeavors and linkages among the players is the main focus of the study. The framework was based on the theory of economic development being a result of three types of factors: primarily, "innovations; external factors such as the government or institutions as weapons of development; and other identified factors of growth or gradual changes in social and economic life which are accomplished through day to day activities and adjustments" (Schumpeter, 1964) like BPM activities and strategic partnership. For Schumpeter, innovation is the chief force in what he calls "economic evolution." Yet, innovations are worthless unless manifested in the changes of the status quo of the lives of the people (Yunus, 2007), new business processes (Huddleston, 2009), and economic management of frequent relations (Bensaou, 1999).

For this academic construct, it was assumed that the main factors that led to the development of the Philippine carabao industry are the innovations on the native carabao as a result of research and technology development. Its repercussions on institutional thrusts as emulated by the creation of the PCC and socio-economic endeavors that were adopted by the traditional network of dairy community industry players in terms of business and entrepreneurial aspects were likewise considered as resultant Vol. 3 No. 1 ISSN: 2507-9638 DOI: 10.22137/ijst.2018.v3n1.04 
aspects of innovation and development. Amidst the novel factors affecting change and on the assumption that structural changes have occurred due to PCC's innovational capacities, the research also focused on the BPM concepts describing the transactional characteristics of the states of carabao milk production and milk processing sectors. These transactional characteristics were based on the entrepreneurial frameworks of operations, production, marketing, financial and intermediary fields of each type of player.

Likewise, the business management principle of Strategic Partnership describing the relational nexus of the players in the carabao milk chain was characterized in terms of coordination and complementation. The assessment of the business to business (B2B) relationships among the sectors resolves the identification of transactional BPM characteristics affecting the interactional strategic partnership factors. Based on the results of the assessment, models of industry development and a configured carabao milk chain were formulated. Furthermore, the research identified sustainability indicators of business and entrepreneurial endeavors within the context of Philippine National Impact Zone in relation to the dynamics of adoption of innovation.

The players on the supply side of the conceptual paradigm refer to the carabao milk producing sector/industry located in Nueva Ecija. They are the smallhold independent and cooperative-based producers, primary cooperatives within the NIZ and institutional players particularly the Nueva Ecija Federation of Cooperatives (NEFEDCO) and PCC-CLSU Techno-Demo Farm. The players on the demand side of the paradigm refer to the pastillas producing sector/industry located in Bulacan. They are composed of the individual milk processors, cooperative processors and organized commercial processors that require carabao milk for pastillas production. The paradigm (Figure I) used in this study illustrates the determination of the significant changes that innovation was assumed to have made on the traditional community-based dairy industry.

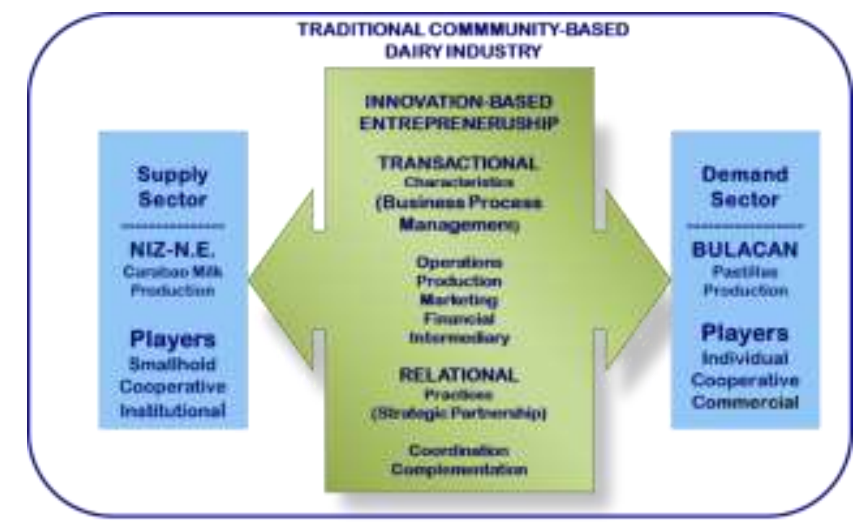

Figure 1. Conceptual paradigm illustrating the B2B factors affecting the entrepreneurial Transactional and Relational nexus of the traditional community-based dairy industry.

\section{METHODOLOGY}

Descriptive statistics, evaluation and analysis of data were used to determine and explain the states of the demand and supply sectors and their entrepreneurial linkages. Field research was undertaken to find out the actual activities and processes within each sector of the dairy community of players and other participants. Chi-square analysis was used to determine the extent of transactional characteristics and relational practices of milk producers and pastillas processors who are either members or non-members of a cooperative. Chi-square is the applicable test for determining relationships of categorical characteristics being investigated using Likert Scale questionnaire format 
(Danao, 2005). Partial correlation was used to determine the status quo (Albright et al., 2003) of the supply and the demand sectors of the carabao milk chain.

\section{RESULTS AND DISCUSSION}

\section{The Dairy Community Players}

The socio-demographic characteristics of the players of the two sectors to be linked are compared. Their characteristics, roles, and individual learnings are based on their occupational position in the industry, organizational types, and transfer mechanisms from one end to another within the industry (Kim, 1993). While the organizational players act and learn through the capabilities of its members, the totality of its organizational actions is not simply the sum of what its members know; rather, it is the collective use of their capabilities and application of learning (Dixon, 1994). In the increasingly becoming competitive dairy industry environment, there is a need to consider the changing characteristics of the various players of the industry to be able to continuously learn and evaluate ways and methods of enhancing the players' abilities in their operations as members of the industry (Massey and Hurley, 1997).

Smallhold Milk Producers versus Individual Milk Processors. Table 1 shows that carabao milk entrepreneurs are married, within the Philippine National Statistics Office working age bracket, and in their prime. Meanwhile, the carabao farmers attained secondary level of education which confirmed the socio-economic standing of the agricultural workers of not being able to send their children to college due to lack of regular source of income and poverty (National Statistics Office, 2004). In contrast, there are now new breeds of processor-entrepreneurs who have been through tertiary education or have attained college degrees, the children of the original pastillas (milk candy) entrepreneurs who now manage the business. It was likewise confirmed that the pastillas business has long been in existence before the proliferation of carabao farming. Further, the table presents the comparative socio-demographics of the supply and demand players showing that on the average, the working age of the milk processors are older than the carabao farmers. In terms of investments, however, the processors have higher capitalization and business valuation and require higher volume of milk for a daily production cycle. They claimed that they have been in the business longer than the institutionalization of the carabao milk raisers (Dela Cruz, 2011: GIS-KI).

Table 1. Relative Profile of Smallhold Milk Producers and Individual Milk Processors

\begin{tabular}{|l|l|l|}
\hline \multicolumn{1}{|c|}{$\begin{array}{c}\text { Socio-Demographic } \\
\text { Characteristics }\end{array}$} & $\begin{array}{l}\text { Smallhold Milk Producers } \\
\text { (Province of Nueva Ecija) }\end{array}$ & \multicolumn{1}{|c|}{$\begin{array}{c}\text { Individual Milk } \\
\text { Processors } \\
\text { (Province of Bulacan) }\end{array}$} \\
\hline Civil Status & Married & Married \\
\hline $\begin{array}{l}\text { Mean Working Age with } \\
\text { Youngest to Oldest }\end{array}$ & 47, from 24 to 73 & 52, from 28 to 88 \\
\hline $\begin{array}{l}\text { Educational Attainment of the } \\
\text { Majority }\end{array}$ & Secondary Level & College graduates \\
\hline Average Family Size & 6 & 6 \\
\hline Average No. of Dependents & 4 & 2 \\
\hline Average Years in Business & 7 years & 27 years \\
\hline Average Initial Investments & PHP $8,600.00$ & PHP 23,000.00 \\
\hline Average Present Value of & PHP 65,000.00 & PHP 223,000.00 \\
\hline
\end{tabular}




\begin{tabular}{|l|l|l|}
\hline \multicolumn{1}{|c|}{$\begin{array}{c}\text { Socio-Demographic } \\
\text { Characteristics }\end{array}$} & $\begin{array}{l}\text { Smallhold Milk Producers } \\
\text { (Province of Nueva Ecija) }\end{array}$ & \multicolumn{1}{|c|}{$\begin{array}{c}\text { Individual Milk } \\
\text { Processors } \\
\text { (Province of Bulacan) }\end{array}$} \\
\hline Business & $\begin{array}{l}10 \text { to 39 liters of milk } \\
\text { produced }\end{array}$ & $\begin{array}{l}50 \text { to } 900 \text { liters of milk } \\
\text { processed }\end{array}$ \\
\hline $\begin{array}{l}\text { Lever } \\
\text { Range of Monthly Income }\end{array}$ & $\begin{array}{l}\text { PHP 6,300.00 to } \\
\text { PHP 37,700.00 }\end{array}$ & $\begin{array}{l}\text { PHP 30,000.00 to } \\
\text { PHP 100,000.00 }\end{array}$ \\
\hline Other Sources of Income & $\begin{array}{l}\text { Farming, odd jobs, vegetable } \\
\text { growing }\end{array}$ & $\begin{array}{l}\text { Farming, remittances from } \\
\text { abroad, catering and food } \\
\text { services }\end{array}$ \\
\hline Trainings Attended & $\begin{array}{l}\text { Carabao raising, milk } \\
\text { production, milk processing, } \\
\text { artificial Insemination, } \\
\text { animal care }\end{array}$ & $\begin{array}{l}\text { Packaging, processing, } \\
\text { food safety and standard }\end{array}$ \\
\hline Training Providers & $\begin{array}{l}\text { Philippine Carabao Center at at } \\
\text { Central Luzon State } \\
\text { University, PCC Main, } \\
\text { Department of Agriculture- } \\
\text { Bureau of Agricultural } \\
\text { Research }\end{array}$ & $\begin{array}{l}\text { Department of Science and } \\
\text { Technology, Department of } \\
\text { Trade and Industry, } \\
\text { Department of Agriculture }\end{array}$ \\
\hline $\begin{array}{l}\text { Y to 11 years } \\
\text { Organizations }\end{array}$ & $\begin{array}{l}\text { Source: Based on survey } \\
\text { Sof }\end{array}$ & undetermined \\
\hline
\end{tabular}

Primary Cooperatives. The cooperatives in which two sets of players belong were established differently (Refer to Table 2). The milk producers established their cooperatives through the efforts of the PCC while the milk processors in Province of Bulacan did it on their own. This data validated the view that PCC was concerned only with the carabao milking farmer sector and did not consider the inclusion of the more established pastillas processing sector which is also a part of the carabao industry. The cooperatives in both sectors were almost similar in their monthly income performance and years in business. Yet, the milk production cooperatives employ more employees and have higher labor turnover rate than their pastillas cooperative counterpart. The cooperative players in the Province of Bulacan are more focused on the milk production side than on pastillas processing. They have been assisted by the Bulacan Provincial Government through the Bulacan Department of Agriculture. In its entirety, the pastillas processing aspect was not grounded on cooperatives or any other organization but was undertaken by the individual and commercial processors independently. There was no active organization that had formally united the processors.

Milk Agents and Collectors. In addition to the end to end players of the carabao milk industry chain, there are milk agents who perform as middlemen between the supply side players and the demand side players. They are individual stand-alone buyers or collectors of milk on a daily basis and deliver pooled collection of milk to the pastillas processors in Bulacan. They would come in their own vehicles like tricycles, motorbikes, or jeepneys, used their own weighing scales, and transfer bought milk into their own containers. They, however, were more visible among the independent smallhold milk producers. They would transact on cash basis and very seldom get advance payments from processors and give advance payments to producers (Martinez, 2011:GIS-KI). 
Table 2. Relative Profile of Cooperative Players

\begin{tabular}{|l|c|c|}
\hline $\begin{array}{c}\text { Socio- } \\
\text { Demographic } \\
\text { Characteristics }\end{array}$ & $\begin{array}{c}\text { Milk } \\
\text { Producers } \\
\text { (Nueva } \\
\text { Ecija) }\end{array}$ & $\begin{array}{c}\text { Milk } \\
\text { Processors } \\
\text { (Bulacan) }\end{array}$ \\
\hline Establishment & $\begin{array}{c}\text { Through } \\
\text { PCC }\end{array}$ & $\begin{array}{c}\text { Own } \\
\text { Efforts }\end{array}$ \\
\hline Years in Business & 10 years & 11 years \\
\hline $\begin{array}{l}\text { Average Income } \\
\text { per Month }\end{array}$ & PHP & $\begin{array}{c}\text { PHP } \\
38,000.00\end{array}$ \\
\hline $\begin{array}{l}\text { Average Number } \\
\text { of Employees }\end{array}$ & 10 & 4 \\
\hline $\begin{array}{l}\text { Average No. of } \\
\text { Years in Service of } \\
\text { Employees }\end{array}$ & 6 years & 11 years \\
\hline \multicolumn{2}{|l|}{ Source: Based on survey } & \\
\hline
\end{tabular}

\section{The Traditional Dairy Community B2B Entrepreneurial Management and Linkage}

Transactional Aspects Between Sectors. The milk producers claimed that they always maintain good business with their customers and their milk deliveries are always bought even if it goes beyond the orders. They usually deliver in the morning or late in the afternoon after milking. Payments are done in cash upon delivery (COD). Milk collectors who would buy the milk from the producers bring it to the milk processors in Bulacan. Sometimes, however, there are rejects based on milk color or taste; some may turn stale while in transport. If these were previously ordered, they were returned and exchanged with fresh ones. During lean months, some deliveries are made on consignment but there are also those that are not paid on time or not paid at all. Due to lack of transportation of some producers, the afternoon produce could not be delivered. The milk processors likewise claimed that they have good business relations with their sources of raw carabao milk. They also maintain various milk collectors who act as middlemen, so that they may be able to fill their requirements for processing. They are concerned with late deliveries because they require freshness in their product output. Late milk deliveries may affect the pastillas' taste, freshness, creaminess, and shelf-life. They sometimes encounter problems on erroneous measures on milk deliveries. This is due to varied oneliter containers used. As a standard, they maintain one liter to a kilo. Some of the processors have difficulty about additional capital for buying milk and collection of payments from distributors. One independent processor opined that "if only they have an active organization that will support them regarding their needs, in terms of supply and capital, it will not take them very long to make their business grow" (Sinaguinan, 2011: GIS-KI).

Relational Aspects Between Sectors. Trust has been a major factor in the relations of the players. Cooperative member producers said that they entrusted their milk sales to their cooperatives and NEFEDCO. This has enabled them to sell all their milk, but at times, they do not receive their payments on time. The recipients of milking carabaos from PCC have contracts regarding the care and other concerns about the animal. Thus, they claimed first-rate support from PCC. Nevertheless, the individual players claimed that they have a hard time regarding communications especially with technicians. This is because the non-member producers are located farther away from PCC. They said that relational connections with customers are "based on the quality of milk" and "guaranteeing that they depend on each other" (Mendoza, 2011: GIS-KI). They have become accustomed to asking about each other's problems and resolving them immediately. Sometimes, they become affected by local 
politics and feel that "they were being used" (Ramos, J., 2011: GIS-KI) especially on the LGUs' milk feeding programs. The processors felt that "they are on their own" because they act independently without any affiliations (Hipolito, 2011: GIS-KI).

Contrasting Transactional and Relational B2B Practices. The contrasting practices of the two sectors in which prospects for linkage management based on improved B2B practices is in Table 3.

Table 3. Contrasting Transactional and Relational B2B Practices

\begin{tabular}{|c|c|c|}
\hline \multirow[t]{2}{*}{ ACTIVITIES } & \multicolumn{2}{|c|}{ CONTRASTING PRACTICES } \\
\hline & $\begin{array}{l}\text { Independent Milk Producers } \\
\text { (Province of Nueva Ecija) }\end{array}$ & $\begin{array}{c}\text { Cooperative-based Milk } \\
\text { Producers (Province of Bulacan) }\end{array}$ \\
\hline $\begin{array}{l}\text { Production } \\
\text { Resource } \\
\text { Care }\end{array}$ & $\begin{array}{l}\text { The independent smallhold } \\
\text { producers }(90.60 \%) \text { do not feel } \\
\text { confident on carabao } \\
\text { technologies because they } \\
\text { claimed to have no and/or less } \\
\text { trainings }(90.60 \%) \text {. }\end{array}$ & $\begin{array}{l}\text { Most cooperative-based }(66.70 \%) \\
\text { smallhold milk producers claimed } \\
\text { that they have enough knowledge } \\
\text { gained from trainings }(66.70 \%) \\
\text { about animal care and milk } \\
\text { production. }\end{array}$ \\
\hline $\begin{array}{l}\text { Product } \\
\text { Handling and } \\
\text { Processing }\end{array}$ & $\begin{array}{l}\text { Only few }(23.80 \%) \text { of the } \\
\text { independent producers follow } \\
\text { technical protocols because most } \\
\text { of them had none }(73.00 \%) \text {. }\end{array}$ & $\begin{array}{l}\text { Cooperative-based producers } \\
\text { always follow technical protocols } \\
(65.20 \%) \text { in milking, health care, } \\
\text { and feeding practices. }\end{array}$ \\
\hline Sales & $\begin{array}{l}\text { Independent producers }(55.70 \%) \\
\text { provide containers for } \\
\text { themselves to be used in selling. } \\
\text { They also have no regular buyers } \\
\text { saved for the milk collectors who } \\
\text { usually came by to collect milk } \\
\text { produce }(63.40 \%) \text {. }\end{array}$ & $\begin{array}{l}\text { Cooperative-member producers } \\
\text { depend on NEFEDCO }(100 \%) \\
\text { regarding sales and containers used } \\
\text { for selling }(52.60 \%) \text {. }\end{array}$ \\
\hline $\begin{array}{l}\text { Transport } \\
\text { and } \\
\text { Distribution }\end{array}$ & $\begin{array}{l}\text { Transport and delivery for milk } \\
\text { produce are not assured for the } \\
\text { independent milk producers } \\
(46.90 \%) \text {. } \\
\text { The independent producers do } \\
\text { not have exacting time schedules } \\
\text { and limits to accord }(48.4 \%) \text { in } \\
\text { milk distribution }\end{array}$ & $\begin{array}{l}\text { Transport and delivery for milk } \\
\text { produce are assured for the } \\
\text { cooperative-based producers } \\
(56.50 \%) \text { due to NEFEDCO's } \\
\text { assistance. Likewise, delivery time is } \\
\text { followed accordingly by the } \\
\text { cooperative-based producers } \\
(57.10 \%) \text {. }\end{array}$ \\
\hline $\begin{array}{l}\text { Market and } \\
\text { Competition }\end{array}$ & $\begin{array}{l}\text { The independent producers felt } \\
\text { that they have many competitors } \\
(65.60 \%) \text {. }\end{array}$ & $\begin{array}{l}\text { Cooperative-based producers are } \\
\text { not very concerned about } \\
\text { competition }(59.10 \%) \text {. }\end{array}$ \\
\hline $\begin{array}{l}\text { Intervening } \\
\text { Factors: Access } \\
\text { to Information } \\
\text { and Pricing }\end{array}$ & $\begin{array}{l}\text { Independent milk producers } \\
(55.70 \%) \text { have no easy access to } \\
\text { information. } \\
\text { The milk collectors or } \\
\text { middlemen have more influence } \\
\text { in pricing than the independent } \\
\text { milk producers }(50 \%) \text {. }\end{array}$ & $\begin{array}{l}\text { The cooperative-based producers } \\
(47.60 \%) \text { have easier access to } \\
\text { information regarding carabao } \\
\text { technology. The cooperative-based } \\
\text { producers have no influence on } \\
\text { price. }\end{array}$ \\
\hline $\begin{array}{l}\text { Communication } \\
\text { With Clients }\end{array}$ & $\begin{array}{l}\text { The independent producers } \\
\text { stated that they have no direct } \\
\text { contact with their end clients }\end{array}$ & $\begin{array}{l}\text { The main client of cooperative- } \\
\text { based producers is NEFEDCO and } \\
\text { they claimed to have direct contact }\end{array}$ \\
\hline
\end{tabular}




\begin{tabular}{|c|c|c|}
\hline \multirow[t]{2}{*}{ ACTIVITIES } & \multicolumn{2}{|c|}{ CONTRASTING PRACTICES } \\
\hline & $\begin{array}{l}\text { Independent Milk Producers } \\
\text { (Province of Nueva Ecija) }\end{array}$ & $\begin{array}{c}\text { Cooperative-based Milk } \\
\text { Producers (Province of Bulacan) }\end{array}$ \\
\hline & $\begin{array}{l}\text { because they usually deal with } \\
\text { middlemen milk buyers } \\
(58.70 \%) \text {. }\end{array}$ & with the institution $(63.20 \%)$. \\
\hline $\begin{array}{l}\text { Customer or } \\
\text { Vendor-Client } \\
\text { Relations }\end{array}$ & $\begin{array}{l}\text { Independent producers gain } \\
\text { customers based on their own } \\
\text { efforts }(73.80 \%) \text {; did not join } \\
\text { associations }(95.10 \%) \text {; most of } \\
\text { their customers are not from the } \\
\text { carabao sector }(91.90 \%) \text {; friends } \\
\text { do not become their valued } \\
\text { clients }(53.20 \%) \text {; most clients are } \\
\text { impersonal and do not have } \\
\text { shared objectives with them } \\
\text { (43.30\%); and would not } \\
\text { cooperate in times of distress } \\
(55 \%) \text {. }\end{array}$ & $\begin{array}{l}\text { For the cooperative-based } \\
\text { producers, new customers are } \\
\text { introduced by former customers } \\
(44.50 \%) \text {; believe that their primary } \\
\text { customer (NEFEDCO) has the } \\
\text { capability as a buyer }(50 \%) \text {; their } \\
\text { customers are always from the } \\
\text { carabao industry ( } 42.10 \%) \text {; friends } \\
\text { become their valued clients ( } 40 \%) \\
\text { so it is very easy to have good } \\
\text { business relations }(85 \%) \text {; they } \\
\text { perceived to have shared objectives } \\
\text { with clients }(57.9 \%) \text {, thus, clients } \\
\text { always cooperate with them }(55 \%) \text {. }\end{array}$ \\
\hline
\end{tabular}

Based on Surveys and KIs

\section{Synthesis and Analysis of the Sectoral Entrepreneurial Management and Linkage}

The carabao dairy industry must not be regarded as confined only to the genetic improvement aspects of the animal and the development of milk production enterprises but has to go beyond. It has to encompass the end sectors affixed to the carabao-based products and not only consider them as extensions but as vital components to contend for the full development of the industry. Milk is a primary good derived from the carabao that has been the subject of merchandising since its domestication and as such, milk production as an activity has evolved as a sector of the carabao industry. With the use of innovations on animal genetics introduced by PCC resulting to increased milk production, the traditional industry was able to embrace change and provide new economic states for the carabao farmers through entrepreneurial engagement. With this end, milk production has been fitted into mainstream agro-food production industry. Yet, in the context of continuous development, it need not end there. It has to seek other avenues to maintain so that it can likewise sustain itself.

The pastillas de leche derives its basic input, the milk, from the carabao. With the milk used in processing, the activity is practically an extension of the milk production sector if not one of its essential facets. Taken as a sector of the industry, it completes and compleats the carabao milk chain. The analysis and synthesis rest on the current status quo of the supply and demand sectors. The present state of the autonomous sectoral entrepreneurial business processes and activities, and the way they maintain their business linkages within their sector provide the supposition of the following discussion.

Supply Sector: The State of Milk Production in Nueva Ecija. The current condition of the milk production players in Nueva Ecija is shown by the favorability and unfavorability of their B2B business process management practices and strategic partnership (Refer to Figure 2). Data showed that the players within the milk production sector have favorable practices in terms of operation, marketing, and coordination. The observed weaknesses were in production, financial, intermediary, and complementation practices as shown by more unfavorable values. 
The operational favorability was reflected in the management of the farmers' major production resource and inventory: the carabao. They are being assisted by the PCC technicians, Local Government Unit-Department of Agriculture (LGU-DA), and National Dairy Authority extension workers in their operational requirements. Producers are also located near each other and converged in one community/barangay, making support for one another straightforward and easy. Marketing for the producers is also favorable due to the presence of the PCC and the NEFEDCO, milk middlemen, and LGU units that require milk for the Schoolchildren Milk Feeding Program. Coordination among the players was observed as also favorable because the players communicate regularly, especially the members of cooperatives, while the non-members communicate through their barangays.

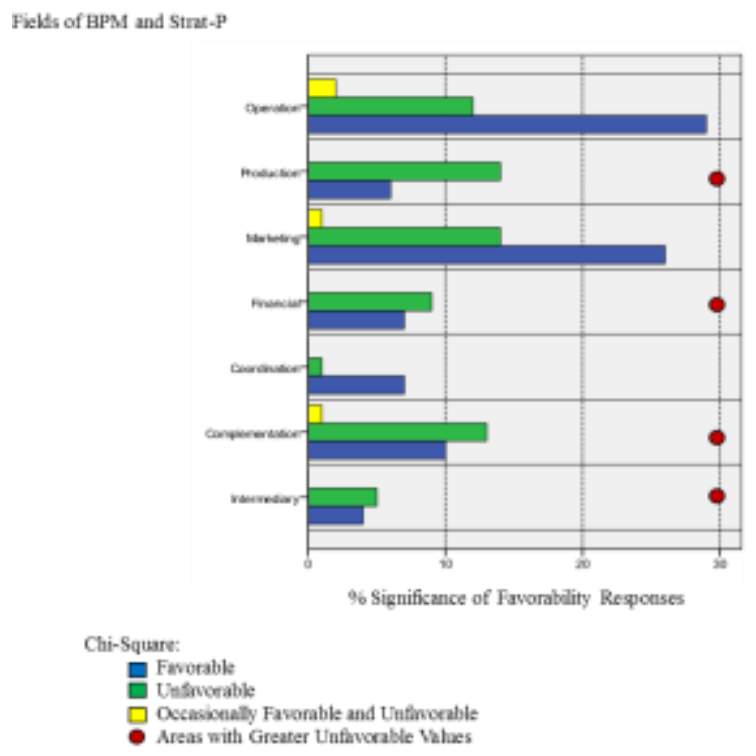

Figure 2. Supply Sector: The State of Milk Production in the Province of Nueva Ecija

The unfavorable situation occurred in the production field of BPM referring to quality control and product certifications, packaging, labeling, technical handling, and processing of products. Majority of the producers do not comply with these because they are still applying the traditional hand milking techniques. The majority of the producers have encountered difficulties in obtaining additional capitalization due to their uneven income receipts. Being engaged in a micro-entrepreneurial undertaking, producers have not been paying their taxes and are not insured along with their animal resource.

Complementation among the players was also unfavorable due to impersonal relations they have with one another as they "feel that they are competing with each other" (Mallari, 2011: GIS-KI). Furthermore, they claimed that they have varied clients who usually come from other communities and that "they always accommodate new and one-time buyers" (Mallari, 2011: GIS-KI) thereby inhibiting their building up of long- term business relations. The unfavorable situation on intermediary factors refers to the access to information and technology by the producers who were not members of cooperatives at the time of the study. Price was also a setback because they could not position standard pricing as it differed from one community to another aside from being set by the NEFEDCO for the cooperative member producers and the prevailing market price for the non-cooperative members (Mayco, 2011: GIS-KI).

Demand Sector: The State of Pastillas Processing in Bulacan. The milk processing sector players indicated favorability in the BPM and Strat-P practices among themselves except in intermediary factors (Refer to Figure 3). 
The favorable operational aspect of the processors was determined by the good ways they have handled their order receipts, inventory management, resource care, and labor management. Pastillas production was seen to be compliant with quality control, handling and processing, packaging and labeling specifications. Marketing for pastillas was not a major concern because their transport, delivery, distribution, competitive market, and feedback after sales situation were claimed to be "in accordance to the needs and requirement of the pastillas consumers" (Trinidad, 2011, GIS-KI). Financial situations of the players were also considered favorable because they have access to loans although this has not been availed of. They pay their taxes and insurances, comply with certification fees, and pay their dues on time. The pastillas processors likewise maintain good communications with each other because they "know them" and "they are their relatives" (Dela Cruz, 2011, GIS-KI). They would "entertain their valued customers very well" and their "new clients to gain trust and long term business relations" (Dela Cruz, 2011, GIS-KI). The unfavorable situations regarding intermediary factors were based on the seasonal sales experienced and the presence of third-party players who affect milk pricing. Other than these, as shown by the findings, the pastillas sector, although small, can very well thrive on its own.

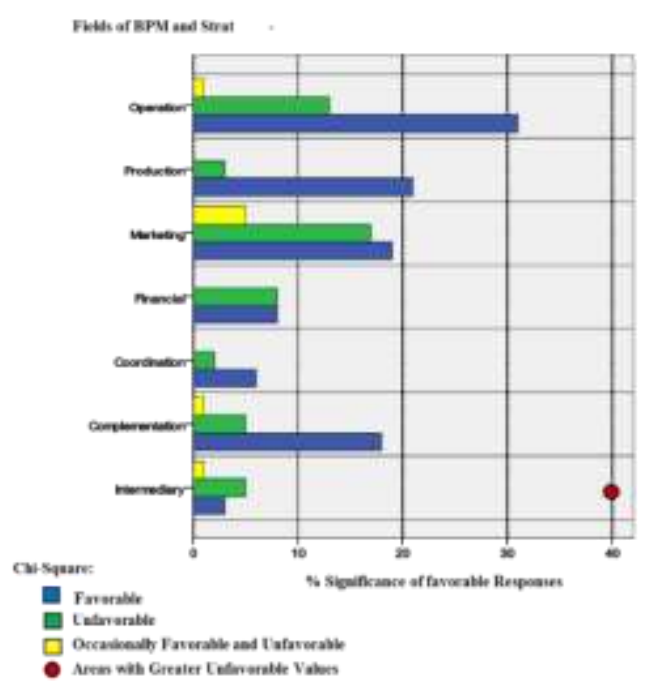

Figure 3. Demand Sector: The State of Pastillas Processing in the Province of Bulacan

\section{BPM Five-Fields Synergy System Model of Management: A Generic Type}

The relationship of the members of a sector, whether in the carabao milk or pastillas sector, is founded on an entrepreneurial link which exposes members to more and better opportunities if given the right management concerns. The focus on relations among sectoral players as a key strategic initiative for development illustrates the importance of the stakeholder theory (Solnet, et al., 2007), relationship management, and generic value chain (Porter, 1985). The link between the stakeholders has always been regarded by chain enthusiasts as a continuous unilateral series of activities inducing change per step and altering an original form into an improved final process or good.

The proposed depiction of an entrepreneurial and management linkage among the players discussed here, refers to a synergy of business to business process activities interlinked together, resulting to a shortened variance among and between the allied players within the sectors. Instead of the conventional supply or demand chain figured along a straight continuum, an innovative synergistic system is introduced to close the gap or minimize the differences among the sectoral players. Having identified the fields of business processes and the specific activities that fall in each and delineate each field, they are combined and illustrated collectively into a basic radial figure representing the BPM FiveField Synergy System Model of Management for Individual/Independent Players (Refer to Figure 4). As a system, each field is able to interact and react with the others and form a working connection. 

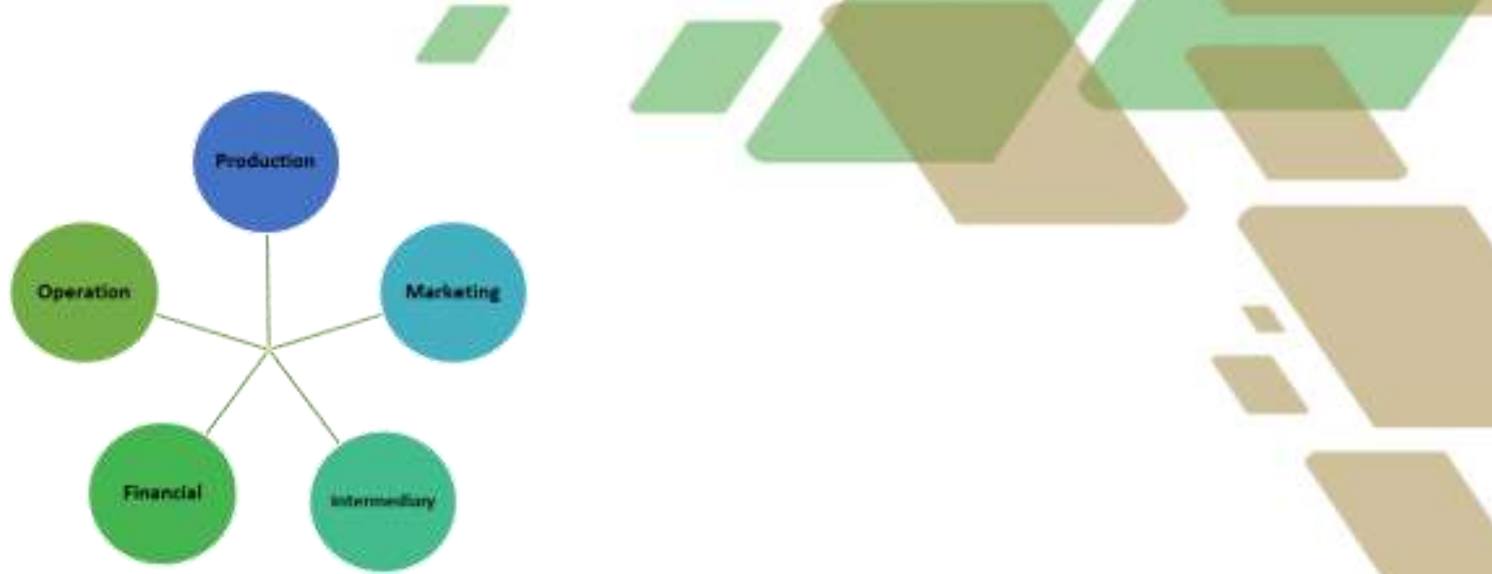

Figure 4. BPM Five-Field Synergy System Model of Management for Individual/Independent Players

The connections among the BPM fields are multifarious yet direct. Any individual/independent player in any sector can function within the synergized BPM system on its own or with another independent player. Thus, each of the smallhold milk producer or individual pastillas processor, cooperative or federation, commercial or institutional player can take advantage of the synergized BPM system and in the end, enhance their core capabilities. To function in tandem as entrepreneurial entities, they have to consider the five fields of operations jointly and collectively and not on a fractional basis. This wholistic approach of linkage management in the traditional and small-scale enterprise is more practical and functional. As each player is a component of a sectoral system, it is imperative for each to establish not only transactional but also relational linkages with one another. Smallhold and individual players have to establish connection with the other sectoral players like the cooperatives, federations, and other institutional and commercial players. In this case, the consideration of the relational aspects is necessary and vital to function well within the sector.

\section{Radial Synergy System Model of Linkage Management: An Innovated Type and its Operationalization}

Considering the strategic partnership practices of coordination and complementation in the field of business process, the BPM Five-field Synergy System Model of Management is further improved. In addition to the generic system, the new fields of relational nature, coordination, and complementation are incorporated and placed as the core of the radial. Figure 4 shows the innovated edition of the basic model, now indicating an orchestrated harmony among the five BPM fields in response to the effect of having a featured hub that can synchronize all fields and activities.

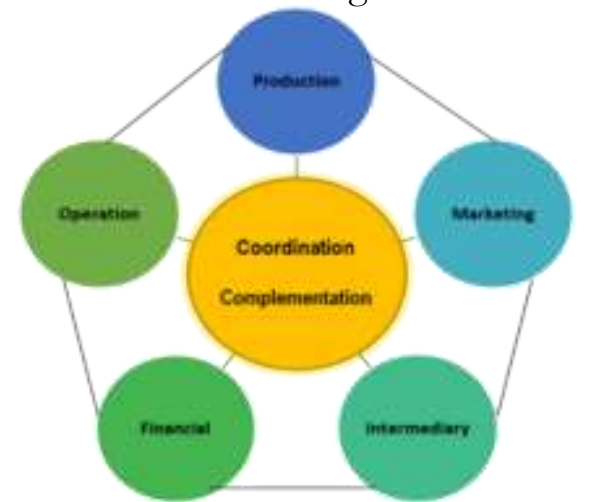

Figure 4. Five-Field Radial Synergy System Model of Linkage Management of Sectoral and Industry Players

The Five-Field Radial Synergy System Model of Linkage Management of the traditional entrepreneurial nexus of sectoral players offers to show the B2B transactional and relational activities tied together in a condensed mold and synergized by a driving force performing the matching process. 
This radial synergy system provides for the interconnection of relationships, directly or indirectly, in a non-chaotic mode because matched activities are assumed to be transaction-specific. With the hub working to match the practices of the players at opposite ends, the players become interlinked and eventually sustain each other. The fundamental importance of the model is that it can make the players depend on each other and in the long run develop and expand together.

In reference to the current condition of the milk production sector where there is higher unfavorability in complementation due to the divergence of membership in a cooperative, a coordinating institution may serve as the unifying entity in bridging the gap between the two groups of smallhold milk production players. The model is reinforced by the favorable coordination among the players mainly due to the "linkages of the cooperative-member milk producer to its primary cooperative which is linked to the NEFEDCO with PCC serving as the coordinating body". In this aspect, the matching of activities of NEFEDCO and its member cooperatives and their individual players is shown in the way NEFEDCO gathers milk produce and delivers it to the commercial processors in Bulacan. Similarly, the non-member cooperatives are being "coordinated by the PCC at CLSU through its technicians and extension workers."

Based on the survey, each of the BPM activities and Strat-P characteristics of the traditional milk sector and pastillas sector players are numerous and varied, but, they are able to form a working relationship according to some commonalities and coordinating institutions (like the PCC Main and the PCC at CLSU for the production sector). The synectic figure corresponds to the actual circumstances in the carabao milk industry where there are still many transactional activities and relational aspects that are of concern and needed to be harmonized between the players in the milk production sector and the pastillas sector. In essence, Figure 5 presents the placement of the Innovated Model within the Carabao supply and demand chain. The Philippine Carabao System is placed at the helm of the two sectors and set to stimulate the B2B relations of the players within the milk producing or supply sectors and the milk processing or demand sector.

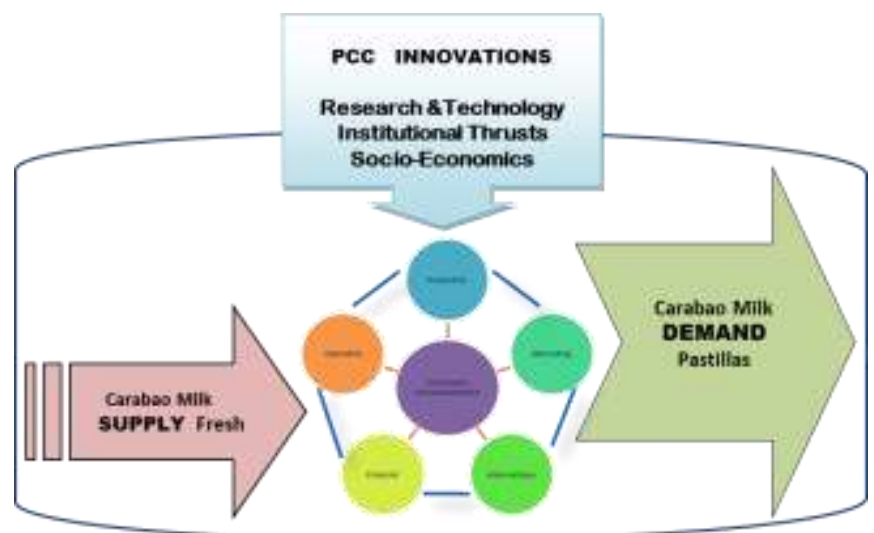

Figure 5. The Innovated Five-Field Radial Synergy System Model of Linkage Management of Sectoral/Industry Players in between the Carabao Milk Chain player

\section{Areas of Opportunities of the Model}

The status of the sectoral players as well as the bi-sector case of B2B entrepreneurial linkage of the carabao industry offer areas of opportunities to synergize as shown by the results of statistical and qualitative information gathered. The application of the model can create benefits for the given traditional community-based carabao milk industry players, such as the following: 
1. Sectoral/Industry Positioning. The agro-food industry offers vast opportunities for entrepreneurs having distinctive products that are unique and of character. Synergizing the entrepreneurial relations of the sectoral players will enclose them into a niche that can earn them a place in the agro-food industry. Having a distinguishable position in the industry, although how small in the beginning, will provide more opportunities in terms of product improvement, business, and going beyond the present market and community.

2. Greater strength. Sectors taken as one can pronounce greater strength in B2B BPM and Strat-P opportunities, more intense bargaining power, and stronger influence over other sectors/industries. Each of the linked players will no longer be regarded as small and trivial because they cater to a small market base, but one to contend with. Capturing each sector as a whole under a coordinating mechanism will strengthen each sector and give each a "voice" in the carabao industry. When the milk production sector and the pastillas processing sector are strengthened, each will gain the distinction as independent players of different capabilities.

3. Capitalizing on capabilities. The distinct capacities of each player can be harnessed and used as BPM and linkage leverage. Still, united players can come up with new and stronger capabilities that can be applied in entrepreneurial deals and transactions outside of their spheres. The innovation in the carabao genetics is one capability of the production sector and the innovative technological applications in milk processing to extend shelf life is another capability for the processing sector.

4. Resource base advantage. With the sectors having the access and ownership of the main resource, the milk, they have all the abilities and influence to control, develop, market and manage the industry. The implementation of the model will further empower the carabao milk resource-based sectors because of their propensity to produce and consume. Each has the ability to direct the different fields in the system through their coordinating institution.

\section{Peculiarities of the Model}

The logistics of administering the submitted model of sectoral engagement creates a range of peculiarities that can be considered in the event of its utility.

1. Not a stand-alone system. The genesis of the model was based on the findings that the diverse players in each sector are uncoordinated. To be effectively operational, the synergy system has to be applied on the transactional and relational associations of two entrepreneurial players of sectors being enjoined. To apply it in confinement is akin to having it done only on a unit organization striving to achieve private internal harmony in management. The model is to be applied among the interconnected sectoral players to gain advantage of it synergistic feature.

2. Affixing not unifying. Players within a sector and sectors within an industry that are not linked and unified are illogical. They must be affixed through a coordinating mechanism so that they can harmoniously perform together. The model presumes affixing, because by doing so, the players retain their identity and still function in unity within the whole. Unification may entail creative destruction of some functions of the individual player which may lead to a new amalgam of transactions and relations within the industry. The model simplifies the holistic involvements of different types of players.

3. Requires a commodity link. As construed, for this sectoral case of B2B entrepreneurial relationship of players, a common commodity has to be identified to be regarded as the basis 
of the linkage and in this case, the carabao milk. Without any commodity link, the model becomes dysfunctional because with a holistic view, there will be no shared aims on which to base the linkage in terms of particular BPM transactions and Strat-P relations. Or, if there is any, it would be very few, making the differences on BPM practices vast and more varied, thereby entailing a reconstruction of the model.

4. Transaction Matching not Cloning. The model assumed the presence of BPM and Strat-P practices among the players that are different but of similar disposition. The synergy system of the model aims to match the different practices that are of similar disposition so that the players can have harmony in linkage. Put differently, to make the practices a clone of the other may destroy the B2B transactions and creation of business relationships. With the model, the players can deal directly with any of the activities along the different BPM fields under the auspices of the coordinating agent, if needed. The shortening of events should be in line with the nature of the commodity link: the very perishable nature of milk.

\section{CONCLUSION AND RECOMMENDATIONS}

Within the framework of the sectoral players, the quantitative and qualitative information gathered catered to the conception of the Five-Field Radial Synergy System Model of Management, which, when impressed on the status quo situation of the sectors, is already partially discernible within and about the five fields of activities. As a matter of information, the entrepreneurial spirit of the pastillas processing sector has been harnessed earlier than the carabao milk production sector. Yet, it is the carabao milk production sector that has been primarily given a plethora of support by the Government of the Philippines through the PCC. The long-standing and popular pastillas industry of Bulacan, which, by all consideration, is a part of the carabao-based industry, was set aside. This situation made up the essence of the introduction of the model for the state of the milk processing sector.

Nevertheless, there could have been concerns that were overlooked in the dissection of the case. Those could have been any of the following: surface-level transactions or characteristics, deeper background information, reality or purely academic issues surrounding the sectors, and a host of other variables not readily apparent to an outsider. Considering the limitations faced by the facts and postulations of the case, it is sufficient for now to basically consider the B2B interactional relations of the sectors and propose for the inclusion of the expanding pastillas sector of Bulacan in the future plans of PCC for the full and total development of the carabao industry, rather than focusing only on the advancement of the NIZ and RIZ models of development.

Based on findings, the issues that could be improved in terms of projects and policy positions are:

a. Inclusion of Non-cooperative Member Dairy Farmers. The imminent strength of noncooperative member carabao milk producers in terms of milk production can be considered in the future plans of the PCC by harnessing their full potentials as carabao milk producers. This is also in line with the move of Nueva Ecija to become the Dairy Capital of the Philippines (Marcelo, 2011).

b. Contemplation and Initialization of Sectoral Collaboration. PCC has to consider in its guidelines the formulation of strategies for inter-sectoral collaboration of carabao-based industries. Particularly, food or commodity sectors within and/or outside the industry can be sustained by carabao-derived products like the milk, meat, and hide. It is also important that PCC moves out of its carabao-focused NIZ realm by including other unorganized existing food or commodity sectors that depend on the carabao as a commodity source of inputs such as the pastillas sector. This will also help sustain the carabao milk production sector. 
c. Reconfiguration of the BPM Field of Marketing and Carabao Milk Chain. PCC has to intensify its efforts in carabao milk marketing research so that it can move along the demand-driven (consumer-pull) carabao milk chain and veer away from its product-driven supply chain marketing approach. This provides for the matching of supply and demand positions of sectors involved based on micro-level solutions of BPM transactional and Strat-P relational aspects. PCC has to realize that on a macro-level, Philippine milk demand still exceeds milk supply as substantiated by importation versus local production despite the claim of increase in milk production (BAS, 2010). Thus, it has to reflect in its policy positions regarding supply provision and draw on linkage policies if it wants the carabao milk production sector to be sustained and able to obtain all economic returns from it. Unless a good policy on marketing and distribution is provided, milk production and processing can only be an exercise in futility.

d. Involvement of the Private Sector. The private sector can provide the needed investments in the modernization needs of the traditional community. PCC has to entice the private entrepreneurs to invest in the putting up of mechanized milking parlors and milk handling equipment to save on efforts and time in relation to quality requirements of freshness and sanitation.

e. Specialization of Sectoral Outputs. PCC has to reflect on the fact that Nueva Ecija was molded and continuously being molded as a carabao milk-producing arena so that it has to focus on this capability and provide structures for its specialization. To venture into the realm of milk processing would make its focus diverge, inducing a sectoral divide within the province. Project initiatives can consider that the milk processing venture be handed to Bulacan that has specialization on the activity so that Nueva Ecija can concentrate on milk production and marketing to jumpstart its aim to become the Dairy Capital of the country. PCC at the same time can instigate policies and projects in support of the carabao milk-based pastillas industry in Bulacan. This will make PCC extend its efforts and not confine its ends only in the NIZ. The NIZ has to evolve and undergo a structural shift from a model to a functional development system spilling over to other communities, sectors, and industries.

f. Replication in other Carabao-derived Products. PCC has already perfected (at most) the milk genetics of the carabao and proven that it was feasible. Thus, it has to venture into the other facets of the carabao: the meat and the hide. PCC has been doing research on these aspects, yet it has not been applied the way they did it with milk: undertaking a full-scale carabao meat and hide production and sectoral linkage model to showcase the viability of the ventures.

g. Conduct of More Research in Relation to Dairy Community Development. With the ripple effects on carabao dairying experienced in non-NIZ communities, research can be conducted on the enterprising aspect related to development. Factors such as cultural, social, business, physical, and even policy environment may be considered. The innovation facet in terms of these factors is important to be regarded and reflected on because it may be able to trigger another blast of creative destruction in its technical (or even social) expressions within the other players in the community.

Noting of the carabao industry's future or any other sectors attached to it, the prayer that the thesis of this research may be reflected on for consideration and use in development purposes, is hoped to become a certainty. 


\section{REFERENCES}

Albright, Christian S., Wayne L. Winston and Christopher Zappe. 2003. Data Analysis and Decision Making. U.S.A.: Thomson Learning, Inc.

Bensaou, Ben M. 1999. 'Portfolio of Buyer-Supplier Relationships', Sloan Management Review, Vol. 40, Issue 4, Summer, pp. 35-44

Danao, Rolando A. 2005. Introduction to Statistics and Econometric. UP Diliman, Quezon City: University of the Philippines Press

Dixon, N. 1994. The Organizational Learning Cycle: How We Can Learn Collectively. London: McGraw Hill

Huddleston, Erik. 2009. Business Community Management. Inovis, Inc.

Hwang, Ming-Hon and and Hsin Rau. 2007. 'Establishment of a Customer-Oriented Model for Demand Chain Management', Human Systems Management, IOS Press, Vol. 26, pp. 23-33

Kim, D. H. 1993. 'The Link Between Individual and Organizational Learning', Sloan Management Review, Fall Issue, pp. 37-49

Massey, Claire and Evelyn Hurley. 1997. Action Research as a Means of Enhancing Dairy Farmer Learning for Management. Palmerton North, New Zealand: Massey University

NEDA-WB. 2007. 7th Framework Programme for Research on Food, Agriculture, Fisheries and Biotechnology, 2007-2013. Pasig City, Philippines: NEDA-WB

Porter, M. E. 1985. Competitive Advantage: Creating and Sustaining Superior Performance. New York, U.S.A.: The Free Press Schumpeter, J. 1964. Business Cycles. New York: McGraw Hill

Solnet, David, Richard Robinson and Chris Cooper. 2007. 'An Industry Partnerships Approach to Tourism Education', Journal of Hospitality, Leisure, Sport and Tourism Education, Vol. 6, No. 1, School of Tourism, The University of Queensland, Australia

Yunus, M. 2007. Creating a World Without Poverty: Social Business and the Future of Capitalism. New York: Public Affairs

Wall, John Edward. 2000. Community Economic Development as a System. M. Sc. Dissertation, University of Guelph, Canada. Retrieved from ABI/INFORM Global, Publication No. AAT MQ47374

\section{Guided Interview Schedule Key Informants}

Dela Cruz, Andrea. January 16, 2011. Commercial Milk Processor and Proprietor-Entrepreneur, Andreas Pastillas, Buliran, San Miguel Bulacan

Hipolito, Leticia. May 24, 2011. Individual Milk Processor and Entrepreneur-Owner, Aling Ine's Pastillas (formerly Letty's Pastillas), Poblacion, San Ildefonso, Bulacan

Mallari, Herminia. January 28, 2011. Chairman, Kapitbahayan Dairy Cooperative, Mabini, General Mamerto Natividad (Llanera), Nueva Ecija

Martinez, Florante, January 29, 2011. Independent Milk Collector, Imelda Valley I, Palayan City, Nueva Ecija

Mayco, Marvin. March 16, 2011. Independent Milk Producer, Small-Scale, Calipahan, Talavera, Nueva Ecija

Mendoza, Virgilio, April 20, 2011. Independent Milk Producer, Buliran, San Antonio, Nueva Ecija

Ramos, Jaime. March 16, 2011. Independent Milk Producer, Semi-commercial Scale, ProprietorEntrepreneur, San Ricardo, Talavera, Nueva Ecija

Sinaguinan, Jennie. May 15, 2011. Independent Milk Processor, San Jose, San Miguel, Bulacan

Trinidad, Melisa O. January 15, 2011. Commercial Milk Processor and Proprietor- Entrepreneur, Ocampo’s Sweets, San Jose, San Miguel, Bulacan 